\title{
Arte y devoción indígena en la Ruta de la Plata Iglesias andinas de los siglos XVII-XVIII
}

\author{
Magdalena Pereira Campos
}

\section{RESUMEN}

En el área surandina, en la Ruta de la Plata entre Cusco, Potosí y Arica, se dio un importante tránsito de artistas, estilos arquitectónicos y ornamentales que es posible apreciar actualmente en portadas de piedra, retablos de madera y pintura mural de los templos, en los pueblos donde transitaron trajinantes llevando la plata hacia el puerto de Arica y víveres hacia la villa de Potosí. En los siglos XVII y XVIII, caciques, cofradías indígenas, maestros cantores y doctrineros asumieron estas construcciones, reconstrucciones y alhajamiento con devoción y compromiso, encargando obras a los talleres artísticos de la zona, como también a artistas locales e itinerantes que difundieron el estilo barroco surandino, adaptándolo a la realidad de las circunstancias sociales de cada comunidad e incorporando iconografías y ornamentos locales.

Palabras clave: ruta, templos, iconografía, ornamentos, barroco surandino 


\begin{abstract}
This article focuses on the cultural universe formed around the silver route, linking artistic and religious expressions that arose there. Collaboration and sharing practiced by indigenous communities before the arrival of the Spaniards made possible the construction and decoration of temples in this commercial circuit. In this sense, the Andean temples are a symbol of the strong relationship between different peoples, as well as their creativity and religiosity. Under Spanish rule, these communities adapted Western models, incorporating iconography and local ornaments. Finally, this South Andean Baroque style spread its influence to different places throughout the region, creating a valuable cultural universe.
\end{abstract}

KeYwords: Route, temples, iconography, ornaments, South Andean baroque

\title{
I. INTRODUCCIÓN
}

En el ámbito geográfico y cultural surandino, desde fines del siglo XVI, por los caminos reales que unían Cusco, Potosí y Arica, se transportaron mercaderías y productos agrícolas, azogue y plata. Estos caminos conformaron la Ruta de la Plata de Potosí.

Los pueblos o reducciones indígenas que se establecieron en la ruta funcionaron como tambos para el trajín. Doctrineros, caciques, cantores y cofradías indígenas asumieron la construcción, reconstrucción y alhajamiento de templos con devoción y compromiso, encargando obras a los talleres artísticos de la zona, como también a artistas locales e itinerantes que difundieron en las portadas de piedra, retablos de madera y pintura mural de iglesias estilos arquitectónicos y ornamentales, donde convivieron elementos iconográficos y decorativos europeos y nativos, consolidándose así el estilo artístico barroco surandino, adaptándolo a la realidad y circunstancias sociales de cada comunidad. 
En este artículo describiremos una selección de templos que conservan portadas de piedra, retablos y programas completos de pintura mural de los siglos XVII y XVIII. Estos fueron lugares de descanso, parada o provisión para las recuas y trajinantes. Pertenecieron a diferentes obispados y arzobispados; su íntima relación se explicaría por su conexión a través de la Ruta de la Plata.

Son tres templos en el camino real entre Cusco y Potosí:

- San Carlos de Puno (Perú)

- Santiago de Pomata (Perú)

- Jesús de Machaca (Bolivia)

Diez en la ruta de Potosí hacia Arica:

- San Lorenzo en Potosí (Bolivia)

- San Miguel de Tomahave (Bolivia)

- Copacabana de Andamarca (Bolivia)

- San Juan de Corque (Bolivia)

- Santiago de Curahuara de Carangas (Bolivia)

- Natividad de Parinacota (Chile)

- San Francisco de Asís de Socoroma (Chile)

- San Andrés de Pachama (Chile)

- San Santiago de Belén (Chile)

- San Bartolomé de Livílcar (Chile)

Estos templos son una muestra representativa del estilo barroco surandino, síntesis de la influencia arquitectónica y decorativa recibida desde los principales centros de la Ruta de la Plata. ${ }^{1}$

1 El contenido de este artículo es parte de la investigación de la tesis doctoral: Arte y devoción en la Ruta de la Plata. Iglesias andinas (s. XVII-XIX). Universidad de Sevilla, España. Lo relativo a pintura mural se enmarca en los resultados de los proyectos de investigación Fondecyt regular N. ${ }^{\circ} 1120562$, 2012-2015: «Transferencias, apropiaciones e interferencias en la pintura mural de las iglesias de la Ruta de la Plata, siglos XVII y XVIII y N. ${ }^{\circ} 1150974,2015-2017$ : «Tensiones entre política 


\section{Trazado y contexto histórico-Cultural de la Ruta de la Plata}

En la cordillera de los Andes, en su parte media, se genera una gran planicie conocida como Altiplano. Con cuatro mil metros de altura, esta comprende el sur peruano, Bolivia occidental, norte de Chile y noroeste argentino. Los lagos Titicaca y Poopó y los ríos que salen de ellos permiten la sobrevivencia en un clima hostil.

En esta excepcional geografía, durante el periodo Formativo (1500 a. C.-500 d. C.), habitaron grupos alto-andinos que domesticaron camélidos y originaron las caravanas de llamas que conectaron el altiplano y la costa. Durante el periodo Medio (500-1100 d. C.) se desarrolló el imperio Tiahuanaco, desde el lago Titicaca hasta los valles occidentales. Los desarrollos regionales, entre los años 11001400 d. C., surgen con la desintegración de Tiahuanaco; entre ellos, la cultura Arica. Con el periodo Inca (hacia 1470), se unifica el vasto mundo surandino.

De la influencia de Tiahuanaco quedan etnias altiplánicas habitando el altiplano peruano, boliviano y chileno, practicando el intercambio con la sierra y valles costeros. Estos grupos étnicos y políticos sobrevivirán en el desierto y se adaptarán a la conquista inca y española, resignificando su cosmovisión (Riviere 1979: 85-91; Murra 2009: 85-86; Durston e Hidalgo 2004: 484, 507-516).

El descubrimiento del mineral de Potosí en 1545 marcó la inflexión en la economía del virreinato peruano. El virrey Toledo, a partir de 1570, fomentará la explotación del mineral, reorganizando el sistema de trabajo incaico, la mita. Los antiguos corredores andinos serán reutilizados como caminos reales para surtir a la villa imperial de Potosí, dirigiéndose hacia Arica, puerto oficial de entrada del azogue (de Huancavelica, descubierto en 1565) y de salida

eclesiástica y participación de la comunidad en las pinturas murales del siglo XVIII realizadas en los obispados de Arequipa, Cuzco, La Paz y La Plata». 
de la plata, desde 1574 (Casassas Cantó 1974: 217-218; Glave 1989; Serrera 1999: 156; Tandeter 1992; Moreno y Pereira 2011: 28-29).

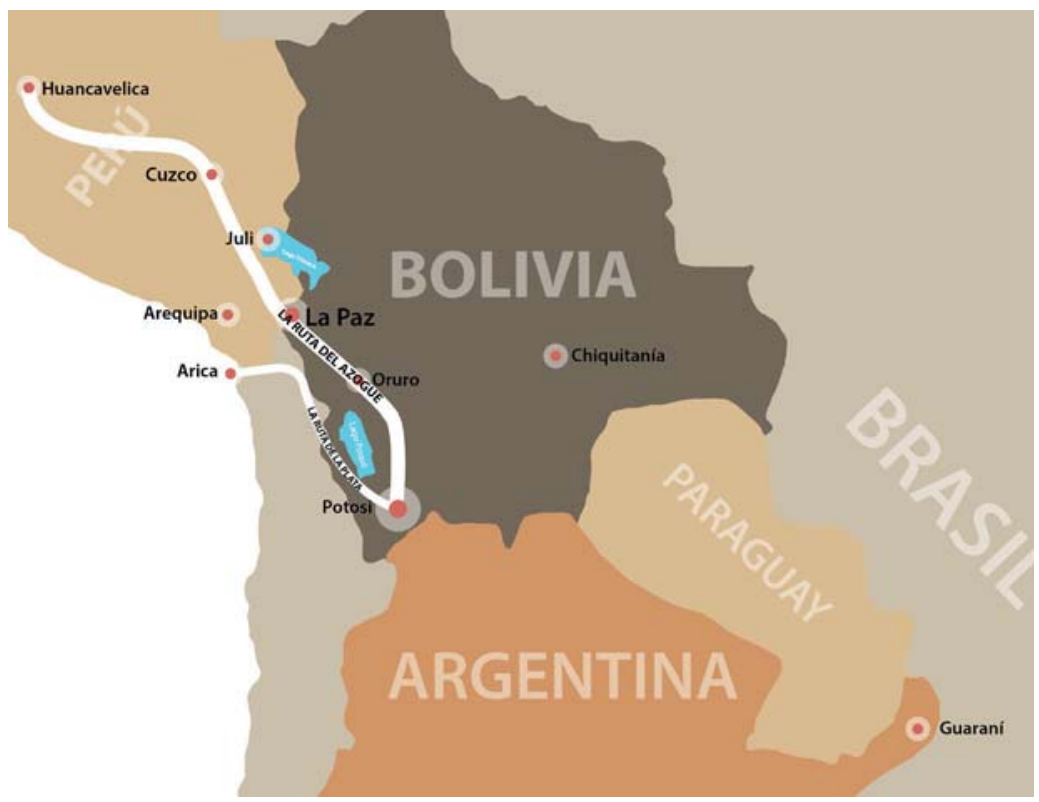

Ilustración con ubicación de templos y rutas en el ámbito surandino.

Diseño: Fundación Altiplano

- Cusco ---> La Paz: Coca, ají, algodón, vino, telas europeas y orientales, madera, pigmentos, lienzos, esculturas (Escobari 2014). ${ }^{2}$ - Arica ---> Potosí ---> Arica: Azogue, telas, vino, productos europeos, orientales y de otros virreinatos (López Beltrán 2015), como también otros productos desde Chile: roble y alerce, que se utilizaron en los retablos de los templos.

2 Con respecto al comercio de productos y telas orientales, se han realizado exposiciones en Estados Unidos con dos publicaciones relevantes. Véase Phipps (2013) y Carr et ál. (2015). 
El camino real desde Cusco salía hacia el sur y se encaminaba hacia el Collao, debiendo subir hacia el altiplano. Desde Vilcanota se llegaba al primer pueblo del Collao, Ayavire. Desde allí a la izquierda se tomaba el camino hacia Omasuyo. Ahí se encontraba Guaycho, actual Puerto Acosta, donde el pintor Leonardo Flores, a fines del siglo XVII, hizo varios lienzos de grandes dimensiones para los templos del Titicaca. ${ }^{3}$

Siguiendo por el camino real se llegaba a Chucuito (junto al lago Titicaca). Aquí residía el curaca principal y había un gobernador. Los pueblos que dependían de este eran Acora, Arvilavi, Juli, Pomata y Zepita (Lizárraga 1908: 83-85).

Avanzando por el camino real hacia La Paz, estaba el famoso pueblo-santuario de veneración de la Virgen Candelaria de Copacabana. Desde Copacabana a la derecha se retomaba el camino real hacia Desaguadero. Más allá estaba el pueblo de Tiahuanaco, corazón del antiguo imperio. De aquí a Calamarca eran dos jornadas largas, donde se juntaba otro camino de Omasuyo. Desde Guarina a La Paz eran dos jornadas. Desde Calamarca se continuaba hacia Caracollo. Desde Caracollo, a una jornada, se llegaba a Sepulturas. A nueve leguas estaba Chayanta. De aquí se seguía al pueblo llamado

3 En el documento, Flores da cuenta detalladamente de su trabajo para la iglesia de Italaque, y las dificultades para proveerse de lienzos y bastidores, y también de colores: «Al pintor del pueblo se le pagó veinte pesos por pintar una cenefa en la iglesia y dar una libra magro, cardenillo y polvos azules. 1 carga de maíz, 1 carnero, 1 peso en plata; 1 carga de chuño [...] Juan Lapitta y Baejse indio a hará el favor de entregar sesenta pesos para enviar colores para que no pare la obra [...] los Bastidores van bien empalmados [...] obren las maderas una, con otra. Firma Leonardo Flores [...] hay aguaceros, la arpillera tiene agujeros que deberá coser Miguel de Lapitta [...] los lienzos son grandes [...] Firma: Leonardo Flores en el pueblo de Guaycho. Dios pague los 60 pesos y dos bastidores [...] que la obra sea de su gusto» (véase Archivo Capitular de La Paz Canónigo Felipe López Menéndez [ACLP], tomo 11: «Cuaderno de los gastos por menor que se hacen en esta iglesia de italaque y han de pasar al libro de fábricas a favor de don Miguel Galaz de los Rios. 1684», ff. 29-35, 44-46; también citado en Gisbert y Mesa [2014: 132]). 
Macha: «en distrito del cual hay una mina de plata que hasta ahora no se ha descubierto ni se espera descubrirá» (Lizárraga 1908: 89). Desde este pueblo se seguía hasta La Plata. Hacia el suroeste, el tambo de Salinas de Yocalla y el cruce del río Pilcomayo anunciaban la anhelada llegada a Potosí (Lizárraga 1908: 89).

Desde Potosí hacia Arica, el camino tomaba la salida sur. Hacia el oeste se llegaba a Chaquilla y luego a Tomahave. Desde aquí al noroeste se ascendía el monte Jatun Mundo Khoriguarani. La ruta seguía por el camino real hasta Parantaca. A treinta kilómetros del río Mulato se llegaba a la antigua capilla Calvario, y, siguiendo hacia el norte, al pueblo de Aroma. En dirección nor-noroeste, una explanada seguía a Belén de Andamarca, cerca del santuario de Copacabana de Andamarca. Desde Opoqueri salían importantes rutas: por el noroeste, a Corque, y al norte, a Turco.

Pasando por Cosapa se bordeaba el volcán Sajama hasta Laguna y Tambo Quemado. Frente a los volcanes Payachatas se llegaba a la laguna Chungará. Parinacota era el último bofedal de la ruta. Cerca de Parinacota, en Chucuyo, se podía bajar hasta Arica por dos senderos diferentes (López Beltrán 2015: 53-68).

Antonio León Pinelo, quien recorrió la Ruta de la Plata desde Potosí hacia Arica y de aquí hacia Potosí dos veces, en 1612 y 1619, ${ }^{4}$ señala la hipótesis de que el paraíso terrenal pudo estar en estas partes altas.

La Ruta de la Plata canalizaba el metal de Potosí y de muchos asientos mineros de la región, llevando su plata a Arica. Oruro y Carangas tenían su propia distribución de azogue; en cambio, los centros menores se aprovisionaban del mismo en Potosí o en Arica, utilizando el camino real o los senderos secundarios.

4 «El parage es bien conocido de los que frecuentan aquel camino que ba [sic] a Potosí, por el nombre de la Puna (que es lo mismo que Paramo) de Tacora y Cosapa: de que puedo deponer por haberle pasado el año de 1612, y otra vez el de 1619, aunque esta segunda sentimos los efectos más violentos porque íbamos de tierra caliente» (León Pinelo 1943: 311-312). 
Por estos caminos transitaron hombres, animales y mercaderías. Los pueblos y tambos fueron puntos clave en el camino. Caminos secundarios o subsidiarios permitían el abastecimiento desde valles aledaños. El tránsito y frecuencia del trajín hizo que el intercambio fuese constante.

\section{EL ARTE DE LA DEVOCIÓN}

La estética y la narrativa de las comunidades de los distintos pueblos de la ruta siguió siendo registrada durante el virreinato en keros, quipus, petroglifos y textiles (Flores Ochoa, Kuon Arce y Samanez Argumedo 1998; Cummins 2002; Escobari 2014; Gisbert y Mesa 2014; Martínez 2010). El virrey Toledo expresa el gusto decorativo que tenían en tiempos incaicos «en paredes y edificios», además de los objetos utilitarios:

[...] ítem, porque es costumbre envejecida que los indios tienen de pintar ídolos y figuras de demonios y animales a quien solían mochar en sus duhos, tianas, vasos, báculos, paredes y edificios, mantas, camisetas, lampas y casi en todas cuantas cosas les son necesarias $[\ldots]$. Y las pinturas y figuras que tuvieren en sus casas y edificios, y en los demás instrumentos que buenamente y sin mucho daño se pudieren quitar y señalaréis que pongan cruces y otras insignias de cristianos en sus casas y edificios (Toledo 1986, I: 39).

Retablos, pinturas murales, lienzos y portadas de los templos andinos pasarán a ser los nuevos soportes de esta tradición indígena, resignificada. Al comparar los ornamentos de los templos en la ruta es posible apreciar detalles que parecieran haberse transferido por el continuo intercambio a través de la ruta más que por la dinámica de un obispado o arzobispado. Teresa Gisbert y José de Mesa señalan el importante legado artístico resultado de la ruta: 
Arequipa se había considerado siempre como el probable punto de origen del estilo mestizo, es posible que tengamos que rectificar este criterio a la vista del ejemplo de Quispicanchis y pensar que el estilo viajó en la ruta de la mita, de Cuzco a Potosí [...]. Es evidente que la constante movilidad de funcionarios y artífices transmitió a través de todo el Virreinato una arquitectura barroca que mantiene poca novedad en la solución de plantas y fuerte carga decorativa en sus portadas (Gisbert 1982: 145). ${ }^{5}$

La mita reorganizó y trasladó grupos de mitayos por periodos anuales, sin desprenderse de su núcleo de origen. Gracias a la riqueza generada por el mineral de Potosí, muchos de los señores locales, entre los que se puede destacar el caso de Gabriel Fernández Guarachi, de Pacajes, amasaron inmensas fortunas que luego se reflejaron en construcciones, tal como la iglesia de Machaca (Choque 2003). También se conoce el caso de Diego Chambilla, de Pomata (Medinacelli 2010: 161).

Las construcciones debían asumirlas las mismas comunidades. También hubo donaciones de obispos, arzobispos o curas párrocos y doctrineros. En el siglo XVII, por ejemplo, se dieron donaciones excepcionales, es el caso del obispo del Cusco, monseñor Mollinedo y Angulo, quien construyó y restauró cerca de 50 iglesias luego del terremoto de 1650 (Villanueva Urteaga 1989); otro caso es el del doctrinero de Salinas de Yocalla, quien, para poder presentarse a oposiciones, financió la reconstrucción del templo para conseguir ser promovido en su doctrina:

Hacia 1750 en Yocalla el Dr Dn Joseph Ignacio de la Cueva y Vibanco cura vicario y juez eclesiástico del asiento de Salinas de

5 La denominación del estilo colonial barroco mestizo se instala a partir de Ángel Guido (1944). Lo consolidan y difunden Mesa y Gisbert (1971: 32-36), y diversos académicos lo siguen utilizando, entre ellos, Okada (2006: 67). Bailey (2010), por su parte, ha propuesto el concepto de barroco híbrido. Sin embargo, el término ha seguido en discusión, no existiendo un consenso absoluto sobre la pertinencia de su expresión para identificar el estilo y el fenómeno artístico colonial. 
Yocalla $[. .$.$] en tiempo de tres años a expensas mias he fabrica-$ do Iglesia toda de nuevo para cuyos gastos pagar a operarios y costeo de materiales me he quitado los emolumentos debidos a mi ocupación enagenandome de mis propios bienes $[\ldots]$ por tanto se ha de servir a Sa Majestad de admitirme en oposición a los beneficios siguientes $[\ldots]{ }^{6}$

Una de las entidades más influyentes en la decoración y alhajamiento de los templos fueron, sin duda, las cofradías. Con origen en las asociaciones de laicos de la Europa medieval, surgieron con fuerza en el virreinato, continuando antiguas asociaciones indígenas. Se componían de mayordomos laicos, organizados en torno a la devoción de un santo y procuraban lo necesario para su altar y celebración. Encargaban obras de arte para alhajar los templos y se organizaban para fabricarlos (Moreno y Pereira 2011: 63-68; Campos y Fernández de Sevilla 2014: 16). Las devociones principales correspondían a Candelaria, Rosario, Inmaculada, Santiago y San José. Las cofradías las adoptaron, surgiendo grandes devociones andinas: Virgen del Rosario de Pomata, Candelaria de Copacabana, Santiago-Illapa, dios prehispánico del rayo. En el caso de San José, promovida en 1560 por el arzobispo de Lima, congregó a carpinteros, albañiles y aserradores (Barriga 2010: 45).

Pomata y Copacabana llegaron a ser grandes devociones en el área de Chucuito, debido a la resignificación del culto pétreo prehispánico que llegó a convivir con las devociones de la Virgen (Stanfield-Mazzi 2013: 38). En Potosí, Fray Reginaldo de Lizárraga describe el poder adquisitivo que llegaron a tener las cofradías. Sin duda, los beneficios de la explotación del mineral de plata se traducían en un buen pasar y en una mayor producción artística:

Las cofradías de Potosí son muchas y muy bien servidas, con mucha cera, y en los días festivos, o de solemnidad de cada una,

6 Archivo Arzobispado de Sucre. Monseñor Santos Taborga (AAS), Oposiciones, ff. s/n. 
confiesan y comulgan los cofrades, con la mayor asistencia. Es pueblo donde se hacen muchas grandes limosnas [...]. Finalmente, Potosí podremos decir es España, Italia, Francia, Flandes, Venecia, Mexico y China, porque de todas estas partes le viene lo mejor de sus mercaderías (Lizárraga 1908: 106).

En Pomata, la iglesia y los santos tenían sus chacras para financiar su culto y fiesta. Sin embargo, la pobreza de algunos años no permitía que hubiese mejoras en el templo y sus bienes muebles. De hecho, al año 1724 se lo señala como el año de «las hambres», coincidiendo con los años en que el templo de Santiago del mismo pueblo padece un «silencio» constructivo y artístico.

En Belén, se fundó tempranamente en el siglo XVII la Cofradía de Nuestra Señora de la Limpia Concepción, poco después que fuese erigida en Arequipa y en Arica. ${ }^{8}$ Esta incidió en la construcción del portal lateral del templo de Santiago, templo que en 1777 estaba reconstruido, y pasaba a ser sede de doctrina. En su arco lateral se conserva la inscripción: «Concebida sin pecado original», en alusión a la desaparecida cofradía de la Limpia Concepción. ${ }^{9}$

Los caciques, capitanes de mita y autoridades locales, como alcaldes de indios y maestros cantores, fueron importantes donantes para los templos, tal es el caso de Cuarahuara de Carangas, Jesús de Machaca, Pachama y Livílcar. Célebre es el cacique de Carabuco, quien entre 1765 y 1785 estaba reconstruyendo el bautisterio de la iglesia de ese lugar, cuya pintura mural donó. El cacique Fernando Siñani aparece representado recibiendo el bautismo, portando un uncu incaico y el sol sobre su pecho (Jemio 1998: 52).

7 Archivo Parroquial de Pomata. Expensas e inventarios antiguos San Miguel de Pomata 1708-1764, s/n.

8 Archivo Arzobispado de Arequipa (AAA), Legajo Arica-Codpa 1650-1893, Tomo 9 1698, Cofradía de Nuestra Señora de la Limpia Concepción del Pueblo de Santiago Tocoroma y Señor de Belén, f. 8.

9 AAA, Legajo Arica-Belén 1694-1856, Inventario de Belén 1850, f. 2. 
Sostenemos, al igual que Millones y Gisbert, que la religiosidad de los nativos se mantuvo gracias al rol fundamental de los caciques, quienes, en general, intentaron conservar los valores indígenas, aunque fuese de manera «solapada» (Millones 1987: 175; Gisbert 1992: 52-53). Esta misma condición asumieron fiscales ${ }^{10}$ y maestros cantores, quienes tuvieron una relación de convivencia cotidiana con los indígenas, sobre todo en pueblos de escasa población, dependientes de sedes doctrinales distantes, donde la visita del cacique y del doctrinero era itinerante, como el caso de los pueblos dependientes de las doctrinas de Codpa y Belén.

Las expresiones artísticas que encontramos en los templos de la Ruta de la Plata recogieron estos valores y los fusionaron con los códigos representacionales traídos desde Europa. A esta síntesis original la denominamos barroco surandino, que se manifiesta con especial claridad en la muestra de templos que hemos seleccionado, en un área geográfica y cultural común, donde conviven íconos europeos, orientales y andinos como representantes paradigmáticos del arte y la devoción en este circuito que unió comercio, fe y creación artística.

\section{LOS TEMPLOS DE LA RUTA}

El origen de los pueblos andinos en la Ruta de la Plata se debe, en gran parte, a las reducciones establecidas por el virrey Francisco de Toledo. La intención era concentrar la población indígena dispersa para una efectiva conquista y evangelización. Para su cuidado espiritual, diversas órdenes religiosas se establecieron en ciudades y reducciones. Los pueblos o reducciones de la ruta quedaron dentro de los obispados de Cusco, erigido en 1537 como sufragáneo de Sevilla, Charcas, en 1553 (elevada a arzobispado en 1609, de la cual pasó a

10 Sobre los fiscales en la evangelización americana y el arte religioso, véase Guarda (2007). 
depender el obispado de La Paz) (García Quintanilla 1964), La Paz, en 1605 y de Arequipa, diócesis erigida en 1609 (Barriga 1952: 53).

Los templos de las reducciones utilizan materiales locales, siguiendo para su tipología y diseño las disposiciones eclesiásticas y las iniciativas de doctrineros y comunidades. Así, se crean templos con espacio al aire libre para congregar a los indígenas, no acostumbrados a ceremonias en lugares cerrados. Surgen templos con atrio, posas y calvarios (Gisbert 1990: 241-246).

Era habitual que la evangelización de las comunidades indígenas se realizara al exterior del templo, donde la religiosidad andina, tan vinculada a la creación y a la vida agrícola, se sentía más cómoda y menos oprimida. El templo cumplirá un rol fundamental en la vida comunitaria de las comunidades andinas, como centro sagrado de devoción y punto de conservación y actualización de las ricas «costumbres» indígenas que sobrevivieron en torno a los atrios y calvarios, junto a los ritos cristianos coloniales.

Mientras se toleraba la continuidad de estructuras prehispánicas como la mita y la utilización del quipu, se imponía una intolerante campaña contra la «idolatría» prehispánica, estableciendo incongruencias en la evangelización.

Por otra parte, iniciativas de doctrineros — como fray Pedro de Gante - y los pictogramas, para la evangelización en México (Cortés Castellanos 1987), y el Ritual Formulario de Juan Pérez de Bocanegra, para Andahuaylillas, promovían la adaptación de la catequesis a la cosmovisión local (Mannheim 2012), dando espacio a la pervivencia, no siempre visible, de ritos, costumbres y símbolos que perduran hasta hoy.

\section{IV/1 Templos del tramo Cusco-Potosí}

a. Puno. Asentamiento de origen étnico lupaca en la ribera occidental del Titicaca, en Perú. En las últimas décadas del siglo XVI, 
registra una población de 4705 habitantes. Perteneció al obispado de La Paz.

El destino de Puno tomó un giro al descubrirse los asientos mineros de San Juan de Alba y San José, hacia 1657. Ese año, José Salcedo descubrió la mina Laicacota, donde se instaló una población a la que se llamó San Luis de Alba. Luego, en 1668, se fundó la villa San Carlos de Puno, como capital de la provincia de Paucarcolla. En 1669, el virrey informaba que el cura Silvestre de Valdez, párroco de la nueva población de Concepción y San Carlos, estaba haciendo la iglesia con su asistencia y trabajo.

La fachada se concluyó el 25 de mayo de 1757 por el maestro Simón de Asto, indígena (según inscripción en la portada), supervisado por el párroco Juan Valentín de Gamboa y Norveña, quien habría gastado mucho dinero en la reparación y adorno de sus iglesias. ${ }^{11}$ La portada del templo fue construida por artífices indígenas. La ornamentación de las columnas incluye representaciones de monos, asociados a la creencia prehispánica de otorgar estabilidad a los edificios, en su calidad de dioses de la construcción (Gisbert 2004: $60)$; es un animal que se representa en vasijas de la cultura Tiahuanaco, como también asociado a uso doméstico y decorativo de alto valor en el altiplano y sierra (Muñoz 1983: 39-46). La reiteración de este motivo ornamental en diversos templos de la ruta corrobora la existencia y aplicación regular de un repertorio formal característico a lo largo de todo su trazado.

El auge minero local permitió que Miguel Jacinto, dueño del yacimiento Apóstoles, al morir en 1778, dejara construidos los muros hasta el nacimiento de las bóvedas del templo. Durante la rebelión de Túpac Amaru, Diego Cristóbal incendia el pueblo; sus habitantes migran al Cusco en 1781 (Gutiérrez et ál. 1986: 149).

11 Archivo General de Indias (AGI), sección V, Audiencia de Lima, Legajo 1565: Informe del Obispo de La Paz, 15 de junio de 1762. Véase Gutiérrez et ál. (1986: 149). 
En 1788 se comenzó a restaurar un grave daño en la bóveda de piedra y muros del templo. Se pide ayuda al cura de San Pedro de Juli para realizar una cimbra de madera para apuntalar, y también al párroco de Santiago de Pomata, para que provea alguno de los arquitectos que trabajan en el vecino templo. En 1794, doña María Brígida Ayala, dueña de asientos mineros, realizó una importante donación, concluyéndose el templo, aproximadamente, 40 años después de la portada (Gutiérrez et ál. 1986: 149).
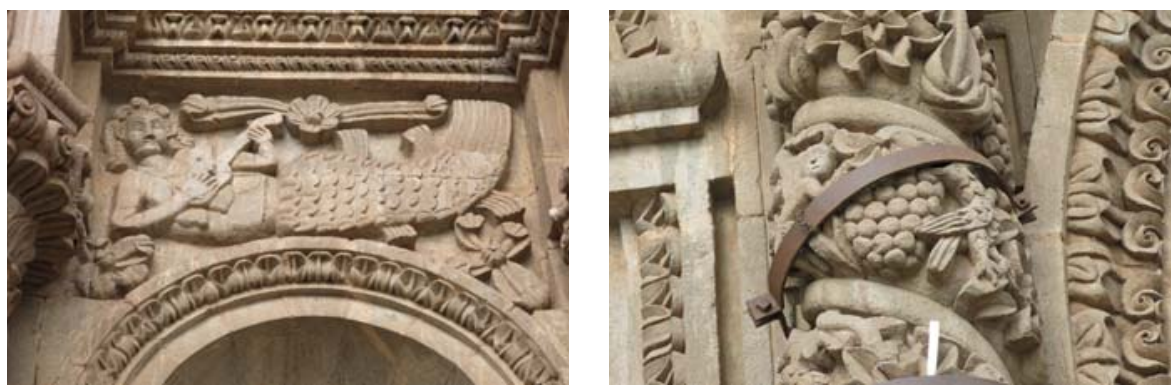

Portada de Puno. Sirena tocando laúd o charango; en la columna helicoidal derecha (desde el observador), un mono toca el racimo de uva. Fotografías: Magdalena Pereira

b. Pomata. Al sur del Perú se ubica el pueblo de Pomata. Su nombre significa «guarida del puma», en quechua y aimara. Fue una importante parada en el tránsito en tiempos prehispánicos, destacado asiento lupaca que perteneció al obispado de La Paz.

Los dominicos se instalaron un poco después de 1540, y hacia 1553 ya habían construido una iglesia y residencia. Con la salida de los dominicos del Collao, en 1572, el templo de Pomata pasó a manos del clero secular; en 1590 fue devuelto a los dominicos por el obispo de Charcas y quedó con una interrupción, entre 1592 y 1600, como su única fundación en el Collao. Fue elevado a la categoría de Monasterio en 1606, mientras eran construidas las iglesias de San Miguel y San Martín. Los dominicos permanecieron en el 
lugar hasta 1754, cuando muere el último cura dominico, fray José Mariaca (Bailey 2010: 236).

La primera iglesia fue construida de adobe y ladrillo y se quemó dos veces, en 1619 y en 1630. A comienzos de 1660 aún era modesta, de una nave, con una torre, atrio y capillas posas. Meléndez afirma que se comenzó una iglesia en 1681; para esta época pareciera ser una iglesia de estructura de madera con ladrillos y adobes (Bailey 2010: 237).

Recién en 1794 se termina la portada de piedra, ${ }^{12}$ similar a una filigrana de ornamento vegetal, que nos recuerda la influencia de la platería en la arquitectura (Pereira 2014), incluyendo monos y vizcachas. La vizcacha no suele ser un animal frecuentemente representado en portadas, sin embargo, está presente en Belén, Livílcar y Pomata. Según Flores Ochoa, Kuon y Samanez (1993: 190-192), para la mitología rural andina, las vizcachas están al servicio de los apus, divinidades que moran en las altas cumbres de las montañas. Para los pueblos del altiplano, las vizcachas se comunicarían con la divinidad, son las mensajeras que acercan a los humanos a las deidades de las montañas. Como intermediarias de los apus, incluidas en las pinturas de los templos, tendrían funciones similares a las de los ángeles de la tradición europea.

La presencia de este elemento decorativo ilustra muy bien el característico mecanismo de transposición utilizado reiteradamente por los artistas locales en las iglesias de la ruta. Ellos incorporaron iconografía propia para representar conceptos a los cuales la tradición europea asociaba otro repertorio formal. Así, los mensajeros divinos ya no serán ángeles, sino vizcachas. El pelaje de su cola era utilizado en textiles, los que solo podían ser portados por indígenas «principales».

12 ACLP, Tomo 101, f. 46v. 


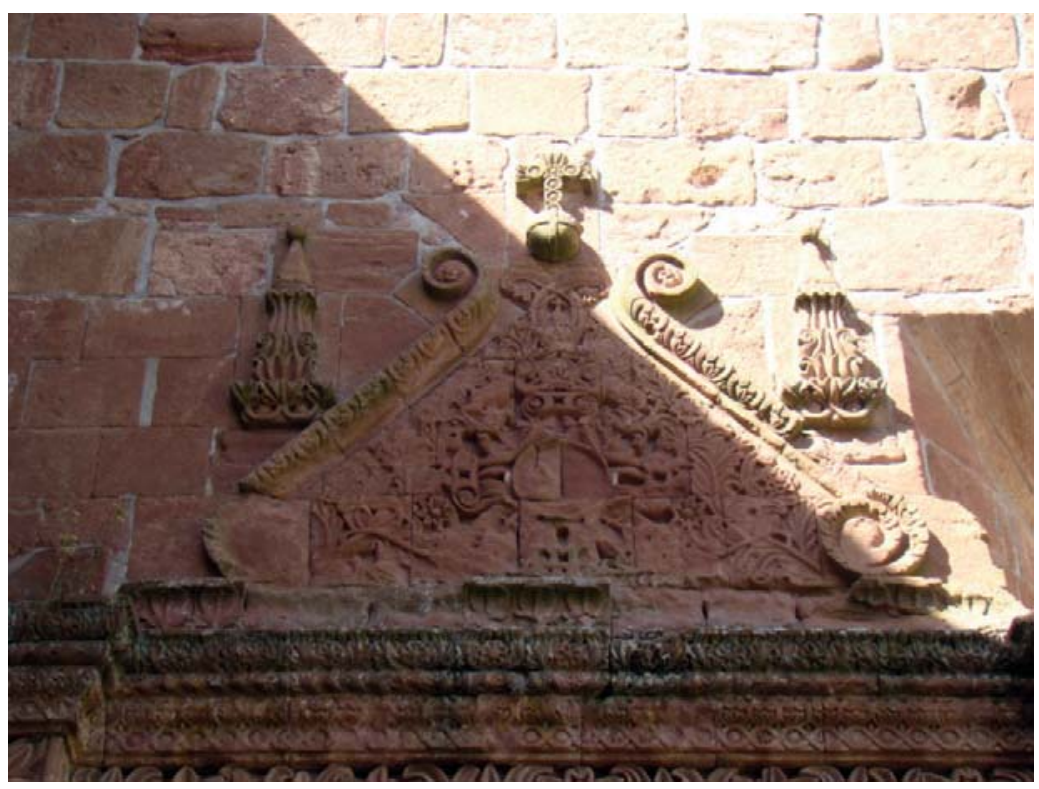

Monos sostienen emblema en el tímpano de la portada lateral del templo de Pomata. Fotografía: Rocío Córdova

c. Jesús de Machaca. Se encuentra en Bolivia, a pocos kilómetros de La Paz, en antiguo territorio pacaje. La iglesia fue inaugurada en 1706. Los historiadores Gisbert y Mesa mencionan que los mecenas que permitieron finalizar la obra fueron el cacique José Fernández Guarachi y el cura Juan Antonio Mogrovejo; sus retratos como donantes fueron pintados en 1706 por Juan Ramos, uno de los representantes de la escuela de pintura paceña del siglo xvIII. Ambos retratos pueden apreciarse en los lienzos sobre el triunfo de Jesús y la Virgen María que se encuentran en una pared lateral del altar mayor (Gisbert y Mesa 2012: 137).

Hacia 1777 se concluyó el dorado de la iglesia. Los maestros fueron Basilio Paredes, Miguel Millares y Bartholome Alegre. Teresa Gisbert describe que los maestros oficiales que construyeron este templo provenían de varios pueblos de los Andes: «Uno de los 
maestros de albañilería, Juan Quispe Huamán era de Cusco; el autor del retablo mayor, Miguel Fernández, había venido de la ciudad de La Plata (hoy Sucre). Otros maestros vienen de Guarina, Achacachi y Chucuito» (Gisbert y Rosso 2008: 93).

En 1807 llegó el pintor Andrés Vergara, de Copacabana, para trabajar en el sepulcro del Señor del Descendimiento. ${ }^{13}$ El templo de Jesús de Machaca se dio el lujo de comprar un retablo de la catedral de la ciudad de Nuestra Señora de La Paz: «El carpintero José Nina Choque armó y acomodó el retablo comprado a la antigua Catedral de la Paz, por el finado cura con recibo del 20 de junio de $1837 »{ }^{14}$

\section{IV/2 Templos del tramo Potosí-Arica}

d. San Lorenzo de Potosí. En Potosí, actual Bolivia, San Lorenzo se fundó como parroquia de españoles con la advocación de la Anunciación. El templo se construyó en 1548, teniendo distintas reconstrucciones hasta el siglo XVIII. Bajo la administración del virrey Toledo, se convirtió en parroquia de indios San Lorenzo de los Carangas, mitayos del cerro rico de Potosí, dentro del obispado de Charcas.

La iglesia tiene una nave única con cúpula. La portada se compone de dos cuerpos labrados con decoraciones florales; las columnas salomónicas decoradas con racimos de uva. Dos mujeres con faldas vegetales, tipo cariátides, sostienen el segundo cuerpo, el cual tiene una figura central de San Miguel en medio de un arco flanqueado por dos columnas estriadas, decoradas con motivos vegetales. En la coronación están san Lorenzo y san Pedro.

En el segundo cuerpo se encuentra la luna y el sol con una estrella. Debajo de cada uno de estos motivos una sirena toca el laúd o el charango. La portada fue atribuida a Luis Niño, indio ta-

\footnotetext{
13 ACLP, Tomo 130, Jesús de Machaca (ss. XVIII-XIX).

14 ACLP, Tomo 130, Jesús de Machaca 1837, f. 144.
} 
llador y orfebre, famoso por su pintura y escultura. La inscripción en su portada es de los años 1728 a 1744 (Gisbert y Mesa 1997: 35). Gisbert sostiene que la asociación del pez del Titicaca con la sirena sería la causa de la proliferación de la sirena en la decoración andina (Gisbert 2004). Sin embargo, María Isabel Rodríguez y Margarita Vila da Vila enfatizan el origen medieval y la representación de sirenas con instrumentos — como el laúd (origen del charango)— en iglesias medievales, dando como ejemplo la sirena que se ubica en el coro de la catedral de Basilea (Suiza). La proliferación podría deberse a copias de grabados o libros iluminados medievales. No se debe dejar de mencionar la asociación de agua y «sirenu» (o «sireno») en el ámbito surandino, dios prehispánico que permite la afinación de instrumentos, lo que podría otorgarle a la sirena su especial proliferación (Millones y Tomoeda 2004).

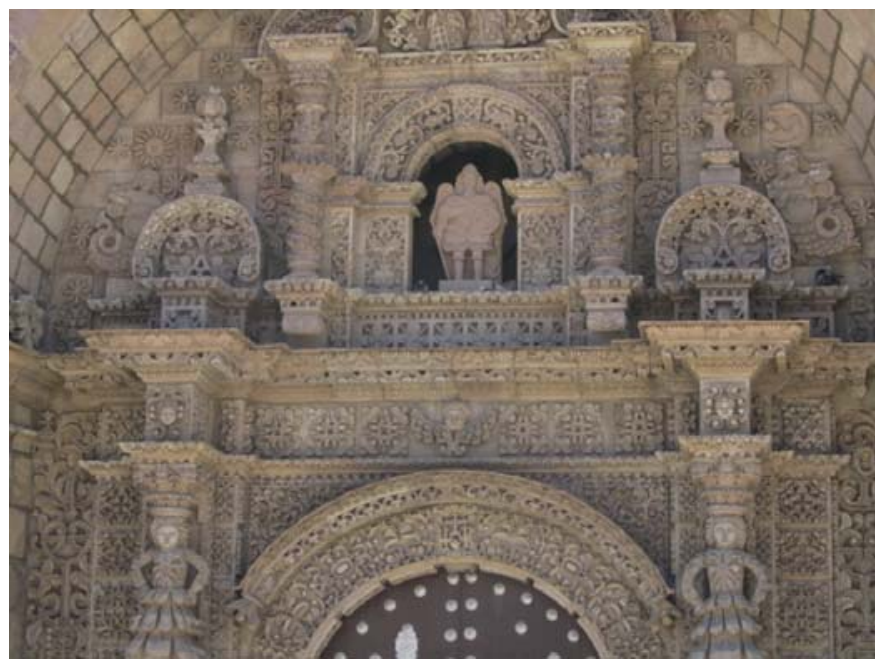

Portada principal de San Lorenzo en Potosí. Fotografía: Magdalena Pereira

e. Tomahave. Fue un importante centro de producción agrícola a $136 \mathrm{~km}$ al surponiente de Potosí. Su templo es de mampostería en piedra y cal en sus cimientos, que continúa hasta un zócalo alto. A 
partir de allí, con muro continuo de adobe hasta llegar a la cabecera, hay un arriostre mixto de piedra o ladrillo. Las bóvedas están realizadas en ladrillo mampuesto.

La portada del templo es bastante inusual. Predomina un arco de medio punto entre columnas, en la planta baja, y triple hornacina, en la planta alta, con un óculo coronando el conjunto. Las columnas son salomónicas y de tres vueltas, decoradas con granadas y racimos de uvas. La decoración que adorna el arco protector y la portada se compone de acantos, palmetas, niños cargadores y rosetones.

En el bautisterio hay escenas similares a las del baptisterio de la iglesia de Carabuco, del siglo XviII. Los muros representan textilería a modo de tapices. El arco que cubre la escena principal también presenta su rosca con el mismo tipo de decorado con «hombres verdes» en las enjutas. La escena principal es «el bautismo de Cristo» bordada con imitación de marco de madera tallado (Jemio 1998: 225-227). La pintura fue realizada por Blas de Ortis, encargada por Joseph Miranda, según consta en un contrato que se efectuó en La Plata en 1725-1726. ${ }^{15}$

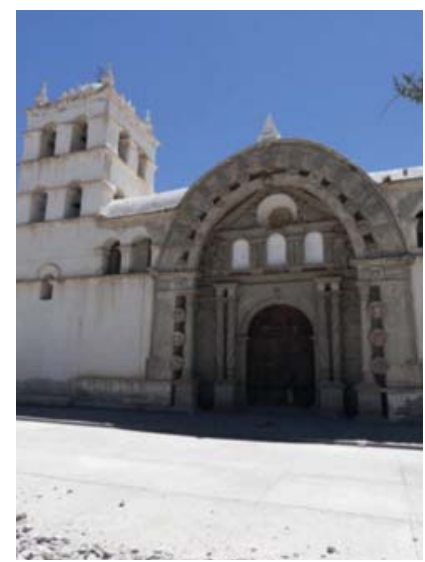

Tomahave. Portada principal.

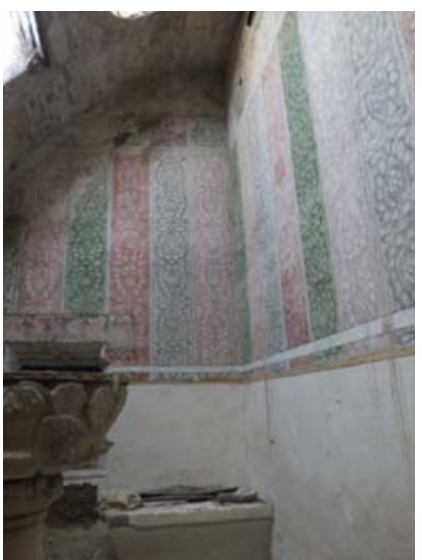

Bautisterio. Murales del XVIII.

Fotografías: Fernando Guzmán

15 AAS, Tomo 8, f. 775. 
f. Copacabana de Andamarca. El pueblo se ubica en la orilla sur del lago Poopó, en Bolivia, en antiguo territorio de los soras, perteneció al obispado de Charcas.

Una leyenda cuenta que «el dueño de una caravana hirió y cazó a una paloma, luego padeció muchos infortunios hasta que consultó a un yatiri. Éste le dijo que la paloma era la Virgen de Copacabana, la cual quería que se construyera una iglesia en el lugar y así quedarían perdonados todos sus pecados. El hombre así lo hizo; además de la iglesia, construyó seis calvarios en los sitios donde descansó la paloma y donde perdió sangre durante su último vuelo» (Shauer 2010: 69).

Esta iglesia tiene planta en cruz latina cubierta por tres cúpulas de arco rebajado. El muro de pies posee una portada sencilla conformada por un arco de medio punto. Fue construida en honor a la Virgen de Copacabana en 1723, exhibiendo una arquitectura de estilo barroco surandino. El techo se cubre con cuatro cúpulas que le otorgan un aspecto exótico tipo morisco. El templo se encuentra en un atrio y hay capillas pequeñas frente a las dos portadas del ingreso; a su lado se encuentra una plaza procesional con cuatro capillas en las esquinas y una capilla miserere en el centro. El interior de la iglesia está decorado con una hermosa pintura mural que data del siglo XVIII, denominada «paraíso celestial», con árboles de tamaño natural en los muros laterales; en el presbiterio se encuentra exuberante vegetación, flores o jardines que muestran la visión del paraíso; se representa el cielo al igual que en Curahuara y Rosapata, pero también está representado el infierno, escenas populares, una procesión, santos y ángeles (Medinacelli y Cárdenas 2013: 209).

La representación del paraíso terrenal es otro motivo recurrente que da unidad estilística a la iconografía que se despliega a lo largo de la Ruta de la Plata. En particular, en Copacabana de Andamarca están presentes los árboles del bien y del mal, granadas, flores, cántaros, pájaros y ángeles. Al igual que en Pachama, en el Juicio Final aparece una alusión directa a la idolatría local, en el que figura un cacique en el lado de los condenados, con una piedra horadada colgando del 
pecho, mismas piedras que es posible encontrar hoy en uno de los calvarios, ubicado en la cima del cerro, frente al acceso del templo.

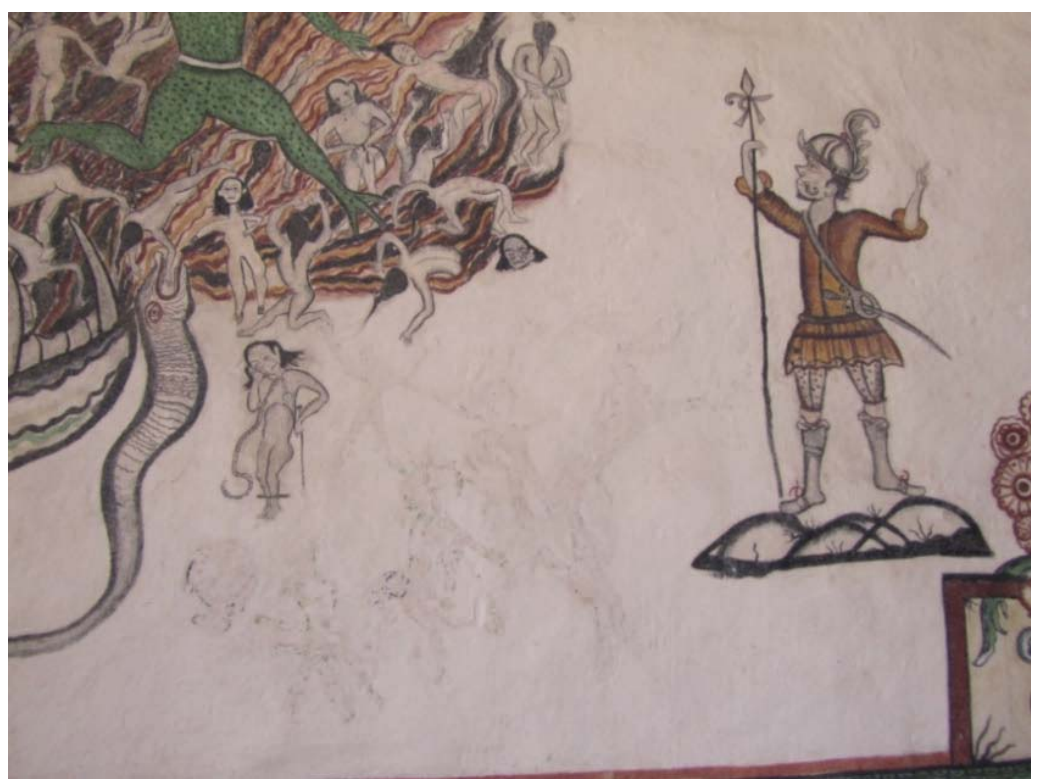

Detalle del Juicio Final, acceso de la nave, muro del Evangelio. Un cacique en el lado de los condenados, lleva atado en su cuello una piedra horadada.

Fotografía: Magdalena Pereira

g. Corque. El primer libro de matrimonios de Corque data de 1561, constituyéndose en una doctrina (Jemio 1998: 141). Corque era denominada como San Juan de Colque Marka, que significa «pueblo de plata».

El sistema constructivo del templo es de piedra, adobe y ladrillo, con planta de cruz latina. El interior del templo fue decorado en el siglo XVIII, colocándose nuevos retablos; también se pintó el alfarje con escenas de la Santísima Trinidad, doctores de la Iglesia, ángeles y flores (Medinacelli y Cárdenas 2013: 214). La ornamentación lateral del retablo del altar mayor, del siglo XVIII, combina una sirena o tritón (Jemio lo identifica con un ser marino o tritón, y Okada, 
con una sirena) que sostiene un racimo de uvas, abajo hay un mono, en la cartonela superior hay un pájaro, un león y frutas (Jemio 1998: 147; Okada 2006: 71). En Cosapa, el remate del retablo tiene a cada costado tallas parecidas a este tritón o sirena.
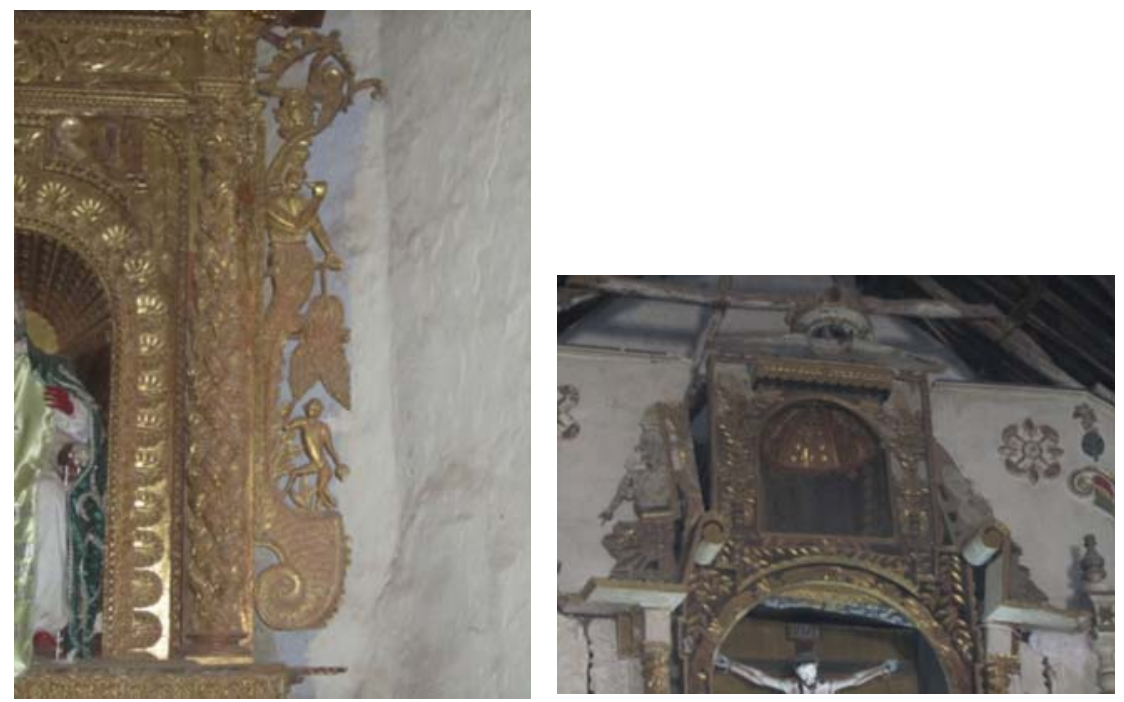

Detalle del altar mayor, tritón o sirena con racimo de uva y mono. Retablo Cosapa. Fotografías: Magdalena Pereira

h. Curahuara de Carangas. Se encuentra en el altiplano andino, en la provincia de Sajama, Bolivia, a 4000 m s. n. m. (Jemio 1998: 150). Fue doctrina dentro del obispado de Charcas. Los carangas formaban parte de un señorío aimara independiente que abarcaba varios pisos ecológicos.

La iglesia, de estructura renacentista, está construida de adobes con techo de paja, teniendo de fachada lateral, al lado del evangelio, su entrada principal con vista al poblado. Su edificación probablemente comenzó cerca de 1580. Interiormente está compuesta de nave, arco triunfal, presbiterio de ábside ochavado, sacristía, baptisterio y coro; el coro alto presenta la singularidad de que se levanta sobre una plataforma de tierra apisonada. 
Está rodeada de contrafuertes y presenta dos torres: una adosada, en el extremo este de la arquitectura, y otra exenta. Tiene atrio y el muro de pies está reforzado por una segunda torre muy extraña que se alza en medio de él.

La portada de estilo renacentista es policromada en rojos y follajería verde. A causa de asentamientos estructurales, en el transcurso de los siglos se fueron añadiendo contrafuertes ciegos y contrafuertes con arbotantes (Jemio 1998: 151-152; Gisbert y Rosso 2008).

En el año 1608 fue pintada gran parte de la nave y el presbiterio del templo. Figuran como donantes el cura Juan Ortiz, el gobernador Baltasar Cachagas y el segunda (persona) Gonzalo Larama. De esta época sobresale el Juicio Final, ${ }^{16}$ cuya representación sigue la iconografía representada por Guamán Poma (Corti, Guzmán y Pereira 2013). En 1777 se pintó otro sector de la nave, coro alto, sacristía y bautisterio (Corti, Guzmán y Pereira 2016).

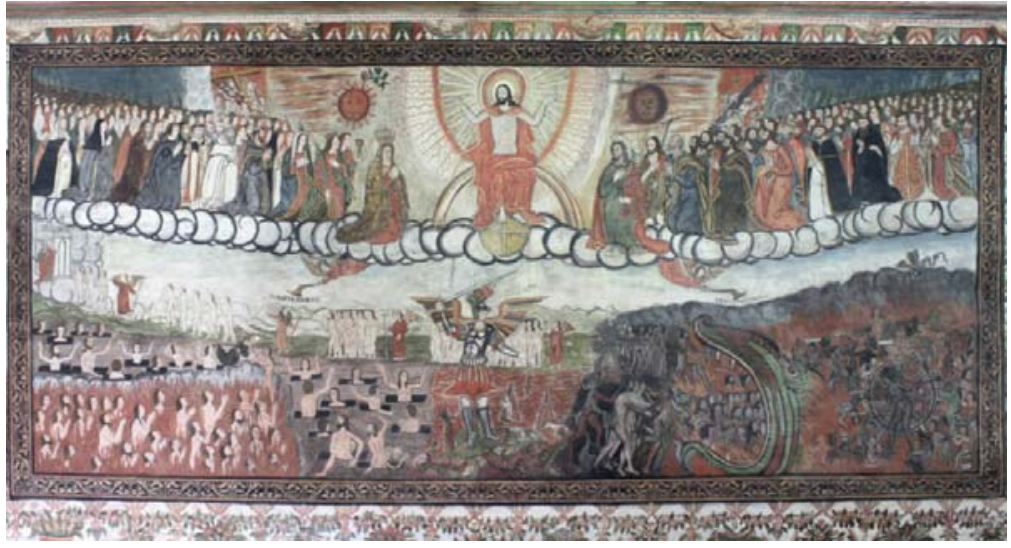

Juicio Final en Curahuara de Carangas (1608) con repintes del s. XVIII.

Fotografía: Magdalena Pereira

16 Sobre el Juicio Final en templos del ámbito surandino, véase Flores Ochoa, Kuon y Samanez (1993); Jemio (1998); Siracusano (2010); Corti, Guzmán y Pereira (2010, 2011, 2013); Gisbert (2001, 2004); Gisbert, Arze y Cajías (2006); Gisbert y Mesa (2014); Cohen Suarez (2016), entre otros. 
i. Natividad de Parinacota. Ubicada en el altiplano de la región de Arica y Parinacota, Chile, era posta de aprovisionamiento para recuas de mulas y llamas; último bofedal en la Ruta de la Plata. Dependió desde 1668 de la Doctrina de Codpa, y desde 1777 pasó a depender de la Doctrina de Belén, en el obispado de Arequipa. Colindaba con la Doctrina de Calacoto en el obispado de La Paz y con la Doctrina de Curahuara.

El templo es mencionado por primera vez en 1739. Tiene muros de albañilería de adobes y piedra, con mortero de barro. El atrio está enmarcado por un muro perimetral de piedra rústica con mortero de barro, con ornamentación de flores de lis y pináculos. Alberga un calvario miserere (Moreno y Pereira 2011: 122).

El portal del muro fachada es de diseño sencillo y composición renacentista, con ornamentación de influencia barroca, elaborada en piedra labrada policromada. La pintura mural es original y data de la segunda mitad del siglo XVIII; el análisis de pigmentos para su restauración arrojó azul de Prusia, inventado a comienzos de ese siglo, y se lo comenzó a utilizar en el virreinato a mediados del mismo. ${ }^{17}$ La pintura presenta elementos típicos del barroco surandino, como animales, vegetación, columnas salomónicas y representaciones religiosas del Juicio Final, san Jorge y el Dragón, san Jerónimo penitente y el Vía Crucis, entre otras. Tiene claras similitudes con Curahuara de Carangas. Es una de las pinturas murales más antiguas y valiosas en Chile (Corti, Guzmán y Pereira 2013). ${ }^{18}$

En el último tercio del XVIII, máscaras de puma se alternan con ángeles alados sosteniendo flores típicas del altiplano; en la escena del Juicio Final un indio trifronte se decide entre la soberbia y el poder, en el marco del cuestionamiento del cacique local en la zona altiplánica (Corti, Guzmán y Pereira 2011).

17 Fundación Altiplano, «Informe para la restauración de la pintura mural del templo de Parinacota», 2008.

18 Sobre los programas murales de Parinacota y Pachama, véase Mebold (1985); Chacama Rodríguez (2009), y Guzmán, Corti y Pereira (2014). 


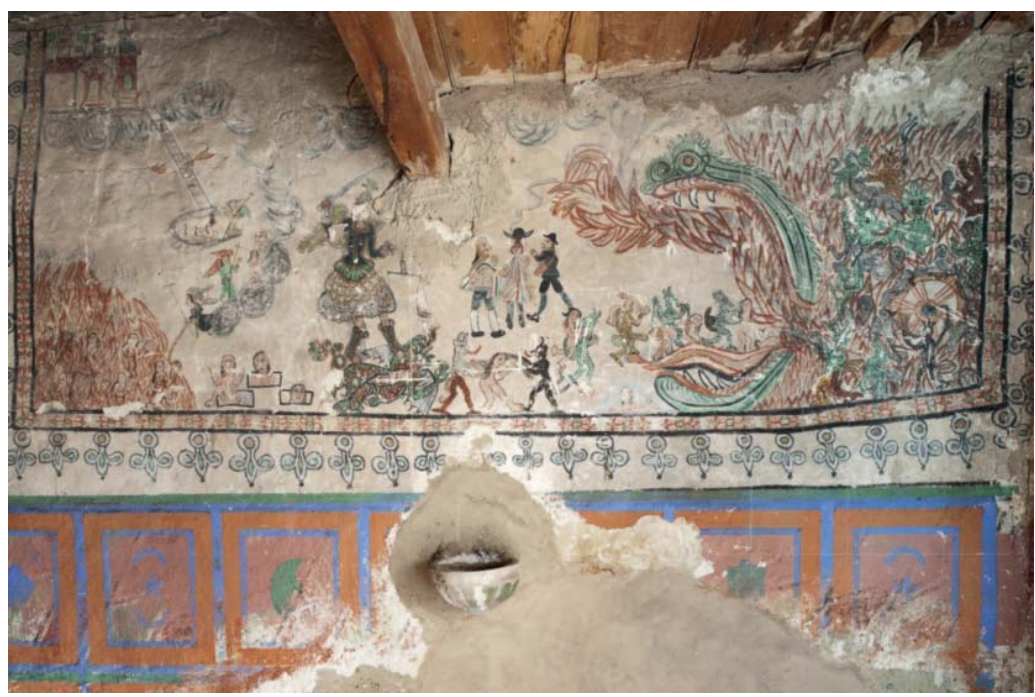

Juicio Final, muro de la epístola, templo de Parinacota. El marco repite la decoración de flor de lis, como en otros templos de la ruta durante el s. XVIII.

Fotografía: Magdalena Pereira

j. San Francisco de Asís de Socoroma. Este conjunto ceremonial católico andino se encuentra en la precordillera, en la región de Arica y Parinacota, en Chile. Dependió desde 1668 de la Doctrina de Codpa, y desde 1777, de Belén, en el obispado de Arequipa.

La iglesia destaca en una explanada, al borde de una quebrada. Su fachada con elementos de un neoclásico republicano corresponde a la fecha de reconstrucción del templo (1883). Tiene planta rectangular sencilla con una capilla adosada en el muro del evangelio, baptisterio y dos capillas adosadas al muro de la epístola. La nave cuenta con un arco toral como antesala del presbiterio. La techumbre tiene estructura de par y nudillo y cubierta tradicional con trama de cañas, estera de totora y paja brava.

Originalmente existió un templo a fines del siglo xvI. Fue reconstruido a fines del xvIII, al igual que el templo de Putre, en 
tiempos del obispo Chávez de la Rosa. En 1833 se incendió y fue reconstruido hacia 1850 y 1883 . El retablo es de piedra labrada policromada, con retícula colonial de dos cuerpos, tres calles, seis hornacinas y un manifestador. Posee influencias neoclásicas republicanas. Constituye un buen testimonio de la reconstrucción de un patrón colonial, con marcas decorativas de estilo neoclásico republicano del xix (Moreno y Pereira 2011: 143).

La portada lateral del templo es uno de sus elementos más valiosos, representante del estilo surandino propio del siglo XVIII. El vano de la puerta de madera de dos hojas está flanqueado por pilastras de piedra labrada, con arco de medio punto que contiene una inscripción ilegible; se reconoce el anagrama de María (MAR), del Espíritu Santo, números romanos como el LV (55) y una pequeña cabeza de ángel alado en la clave. Las pilastras presentan ornamentación vegetal y la figura de dos leones, expeliendo fuego a cada costado, similar tipología a aquellos ubicados en las orlas de la fachada principal de Puno. El portal se volvió a colocar luego de una reconstrucción, se deduce que con desconocimiento del calzado original de las piezas de piedra labrada (Pereira 2013).

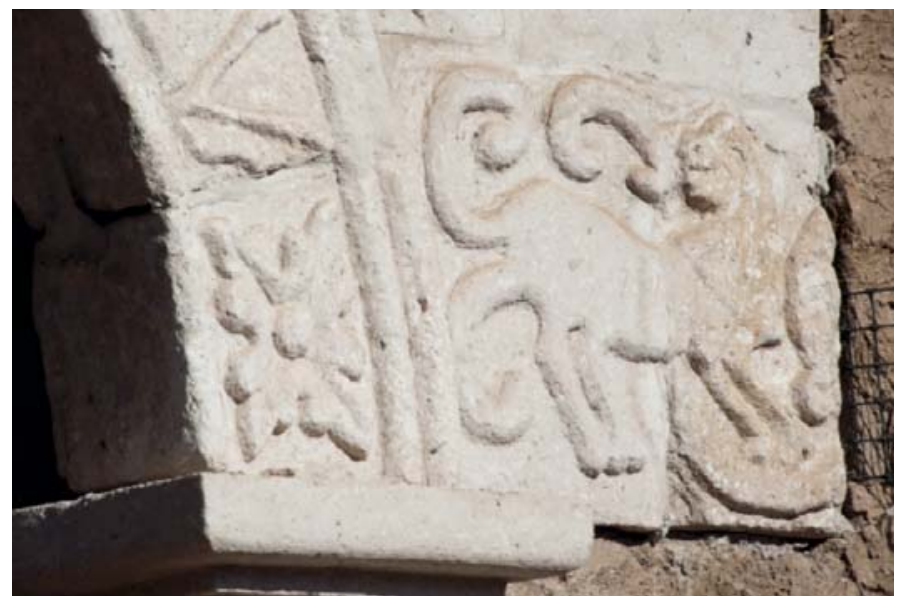

Detalle de la portada lateral, Socoroma. Fotografía: Magdalena Pereira 
k. Pachama. En la misma región y piso ecológico se ubica Pachama. Músicos, loros y máscaras de felinos decoran la iglesia de San Andrés, cuya virgen tutelar era la Virgen del Rosario, hoy en día celebrada como Encarnación. Dependió desde 1668 de la Doctrina de Codpa, y desde 1777, de Belén, en el obispado de Arequipa.

El primer registro de una iglesia en Pachama es de 1739. En 1787 se afirma que Pachama se encuentra distante «tres leguas del camino real de Potosí». La iglesia tiene muros de albañilería de adobe. Su portada es de ladrillo rústico. El atrio está enmarcado por un muro perimetral con ornamentación, rematado con una barda de paja. El retablo del altar mayor está compuesto de una base, un cuerpo, ático y tres calles. Los nichos del retablo se incorporan al muro testero de la iglesia y están enmarcados con madera tallada policromada.

En 1793 se menciona una iglesia en Pachama con pila bautismal. En 1873, se tiene registro en el libro de fábrica de recursos dejados en Pachama para el arreglo de su iglesia por «estipendios de cofradía». A mediados del siglo xx, el capellán militar describe parte de su valiosa pintura mural. En 1992 se cambió el piso original de tierra apisonada por baldosas, con fondos reunidos por la comunidad de Chapiquiña (Moreno y Pereira 2011: 136).

La pintura mural data de la segunda mitad del siglo XVIII; en el presbiterio, la pintura se compone por la representación de santos enmarcados por columnas helicoidales. En el muro del Evangelio, san Isidro labrador protege las terrazas de cultivo, san Miguel Arcángel pisa un dragón semejante a una hidra de siete cabezas (se vincula a la leyenda local del temor a la serpiente que se convirtió en una piedra de siete partes) (Guzmán et ál. 2016). Esta tipología se repite en el templo de la Virgen Remedios de Lagunas, ubicado en la ruta, pintado en 1876 por el artista Ciriaco Acuña, escultor y pintor de Cochabamba. San Cristóbal y el niño, el Ángel de la guarda y san Jorge (este último tiene el mismo diseño del que está representado en Parinacota), en la epístola. El acceso de la nave, en ambos muros, 
presenta ornamentación vegetal, flores, pájaros, imitación de textiles y azulejos.

En el muro de pies, al interior, el maestro cantor preside el coro alto con un poncho o uncu de diseño local, rodeado de niños; a los costados, músicos tocan arpas barrocas. En 2008 fueron encontradas en el coro alto de Parinacota este tipo de arpas en desuso. Podríamos vincular esta escena a los ángeles músicos pintados en el XVIII en el coro alto de Curahuara y en la techumbre de Belén de Huachalla. Abajo, escenas costumbristas muestran mujeres que escuchan atentamente la seducción del arpa, mientras otras se confiesan. En el tímpano exterior, la Virgen del Rosario (en la tipología de Pomata) está acompañada de san Andrés, patrono del templo, y san Pedro, apóstoles hermanos.
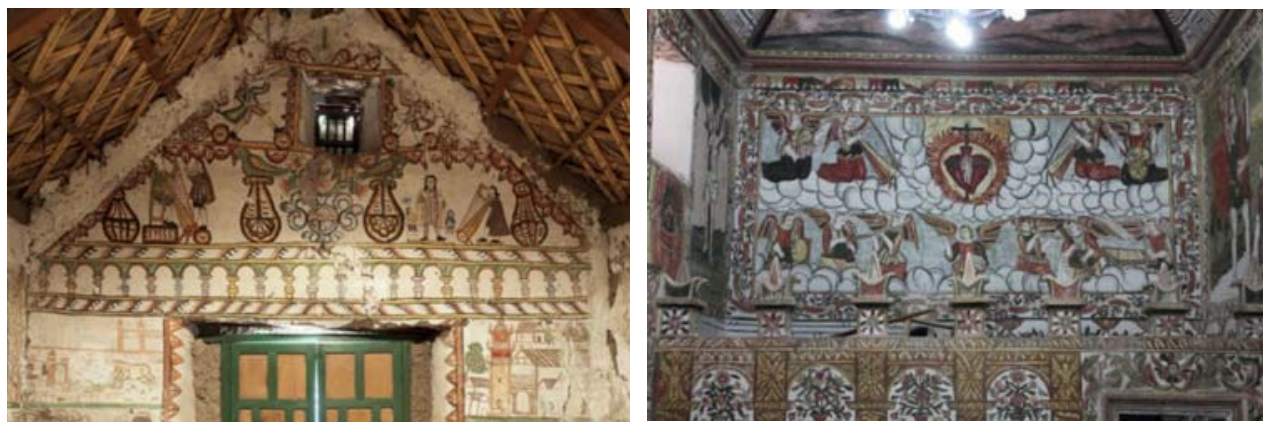

Representación del coro alto, con maestro cantor y músicos, Pachama.

Curahuara de Carangas, ángeles músicos en coro alto. Ambas del s. XVIII.

Fotografías: Magdalena Pereira

1. San Santiago de Belén. Templo ubicado en Belén, en la región de Arica y Parinacota. Dependió desde 1668 de la Doctrina de Codpa y en 1777 fue cabeza de Doctrina de Belén, en el obispado de Arequipa.

En 1618, Vásquez de Espinoza se refiere a una iglesia en Tocrama, a la cual le colocó puertas de palos. En 1739 se menciona una 
iglesia principal de San Santiago de Belén. En 1777 se describe la iglesia de fábrica de adobe con portada y arco toral de cal y piedra blanca, toda ella «pintada finamente» y amplia para la feligresía. ${ }^{19} \mathrm{La}$ techumbre es de madera, estera de caña y cubierta de paja; la iglesia cuenta con sacristía y bautisterio. Los muros son de albañilería de adobe con mortero de barro. El retablo del altar mayor actual está compuesto de una base, un cuerpo y tres calles, construido en madera policromada y ornamentado con motivos vegetales y columnas salomónicas, coincide con la descripción del inventario de 1850, aunque ha sido intervenido (Moreno y Pereira 2011: 122).

En 1850 se describe la iglesia con cementerio, torre, coro alto con balaustrada de madera, órgano en mal estado y púlpito. El altar mayor se describe todo dorado y cuenta, además, con altares policromados en las capillas laterales. En 1873 la iglesia se encuentra en estado regular debido al terremoto de 1868 y se solicita al párroco reparar el piso del presbiterio, la techumbre de la sacristía y el campanario. En 1954, el capellán militar Luis Urzúa destaca la existencia de ricos ornamentos sacerdotales. El temblor de Arica, en 1987, derribó la cúpula del campanario, que luego fue restaurada. En 1991 se cambió el piso de la nave por baldosa y la cubierta del techo, reemplazando la paja brava original por planchas de zinc.

El portal del muro fachada correspondería a 1777. Se compone de un tímpano con figura de Santiago Matamoros y ornamentación vegetal; columnas salomónicas con sirenas tenantes, decoración vegetal y animal y, a cada costado, tallas de ornamentación vegetal junto a los emblemas reales: el león, la espada y la corona real. En las columnas salomónicas se esconden vizcachas, un hombre puma y un mono.

19 Ministerio de Relaciones Exteriores del Perú. Departamento de Archivo de Límites, n. Ari-1. Legajo 416. Siglo XVIII. Inventario que se hace de la Iglesia. Número de folios: 65. Años: 1778-1837. 

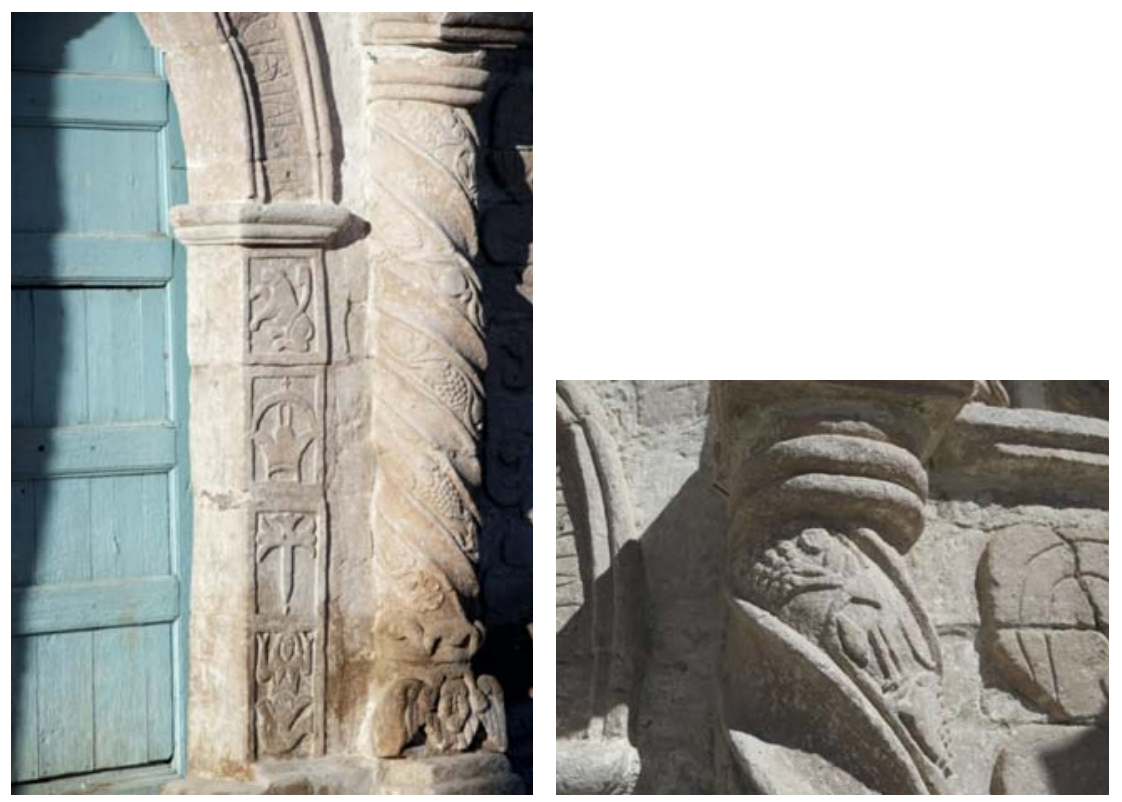

Sirena tenante en la base del pilar de la portada principal de Santiago de Belén. En la parte superior de la columna helicoidal un mono toca el racimo de vid, y debajo de él se esconden el hombre puma y una vizcacha. Fotografías: Magdalena Pereira

m. San Bartolomé de Livílcar. En el valle de Azapa, región de Arica y Parinacota, que dependió desde 1668 de la Doctrina de Codpa, en el obispado de Arequipa.

La primera mención en documentos de un templo en Livílcar es en 1739. Sin embargo, en su portada está inscrito el año 1728. Un año antes, un Diego Cañipa fue nombrado alcalde mayor de Livílcar, Tignamar, Saxamar y Humgata (Hidalgo 2004: 528). Livílcar, pueblo de origen del linaje Cañipa, coincidentemente tenía su iglesia concluida un año después. La complicada situación del cacique Diego Felipe Cañipa, en el contexto de las rebeliones que se estaban gestando desde comienzos de siglo, en distintos pueblos de la ruta, pudo haber motivado su decisión de donar una campana que lleva 
inscrito su nombre, datada en 1779. Cañipa, pocos años después, fue desollado públicamente en el pueblo principal de Codpa por seguidores de Túpac Catari.

La materialidad y sistema constructivo corresponden a albañilería en adobe con mortero y revoque de barro. El retablo del altar mayor es considerado como uno de los más valiosos conservados en Chile, en madera de cedro dorada, donde destacan dos ángeles turiferarios con penachos de plumas, en el Manifestador.

En 1793 se describe la iglesia de Livílcar como una viceparroquia de 20 varas de largo y 7 de ancho, con baptisterio con pila bautismal, sacristía, torre campanario y cementerio. Se vuelve a mencionar el templo en 1873 y en 1907. El campanario, originalmente, tenía dos cuerpos; fue removido entre 1949 y 1953 por su mal estado. En los años 80 se derrumbó la sacristía y el bautisterio. Hoy sólo se conservan cimientos de esta última pieza (Moreno y Pereira 2011: 134).

La portada en sus columnas helicoidales integra imágenes de pájaros, racimos de uvas, granadas, flores y vizcachas; en los capiteles, ángeles y niños. En el templo de Livílcar fueron descubiertos murales en el año 1996. Los restos dan cuenta del estilo barroco dieciochesco, con un ajedrezado en la base, ornamentos, cestos con frutos, pájaros y ángeles, entre otros. 


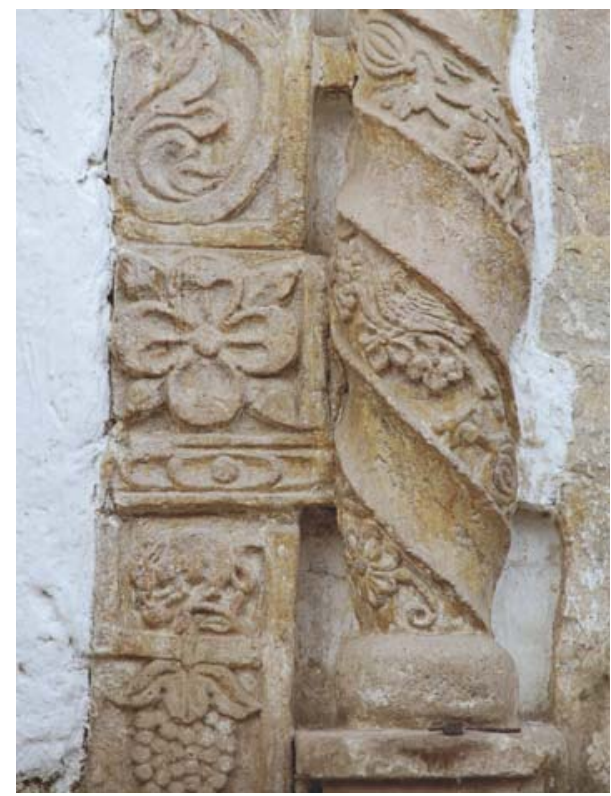

Detalle del pilar que flanquea la columna izquierda, desde el observador; sobre el racimo de vid, una vizcacha. Fotografía: Magdalena Pereira

\section{Conclusiones}

Este artículo propone una mirada integral al universo cultural que se conformó en torno a la Ruta de la Plata, vinculando las manifestaciones artísticas surgidas allí con la devoción religiosa inspirada por formas locales de arte sacro y la existencia de un circuito comercial vigente durante más de dos siglos.

La superposición de estas tres dimensiones - económica, religiosa y artística - cristalizó en el trazado de la ruta y dio vida a una expresión artística original y reconocible como estilo barroco surandino.

Las claves formales de este estilo revelan la convergencia de las creencias prehispánicas y el mensaje evangelizador de la Iglesia 
católica, en concordancia con la Corona española; la iconografía de los pueblos prehispánicos, fusionada con el repertorio estilístico traído de Europa.

Esta síntesis solo pudo lograrse con la participación activa de las comunidades originarias. El mejor ejemplo de esta manifestación creativa lo encontramos en la construcción y ornamentación de templos en este circuito comercial con difícil logística. Sin la colaboración y el intercambio practicados por las antiguas comunidades desde antes de la llegada de los españoles habría sido muy difícil emprender las tareas de construcción y decoración de nuevos templos, que simbolizan relaciones familiares o étnicas entre distintos pueblos, su creatividad y su religiosidad.

La política de la Corona aprovechó aquellas costumbres prehispánicas de utilización de fuerza laboral y recursos naturales, permitiendo un diálogo fecundo entre materiales y estilos artísticos, con una adaptación local de modelos occidentales e incorporación de iconografía y ornamentos locales. Resultan muy significativas las coincidencias en el ornamento y decoración de los templos que fueron reconstruidos durante el siglo XVIII. Uno de los motivos comunes más característicos es la representación del paraíso terrenal. En todos los casos, la iconografía reitera árboles del bien y del mal, flores, cántaros, pájaros o ángeles músicos.

Esta «reafirmación de la fe», como la llaman Flores Ochoa, Kuon y Samanez $(1993,1998)$, se da en el contexto de las rebeliones sociales que desde comienzos del XVIII se fueron gestando y detonaron el levantamiento de Túpac Amaru y Túpac Catari (Walker 1999; O’Phelan Godoy 2012). Esta reafirmación fue escenificada y representada utilizando el repertorio formal que se configuró y consolidó gracias al tráfico de ideas e influencias que fluyó a lo largo de la Ruta de la Plata en el transcurso de más de dos siglos. Tampoco es casual que sean los templos el soporte distintivo donde se expresó esta original síntesis estilística. La Iglesia, especialmente después del sínodo diocesano de La Plata, aprobado en 1773, promovió activamente la 
decoración y redecoración de los templos de la ruta para fomentar una catequesis didáctica (Guzmán et ál. 2016).

El propósito fundamental era que las iglesias estuviesen «pintadas y adornadas de forma que muevan al culto y reverencia, sirviendo de historia y libro donde se lea, y considere lo que se ha de imitar y seguir, y no resulte la menor indecencia» (Sinodales 1854: 143). El sínodo de 1773 tuvo una circulación notoria; en 1794 se recomienda su lectura en el obispado de La Paz. ${ }^{20}$ En esos últimos años del virreinato peruano, esta intención didáctica se transformó, pues, en un verdadero programa de creación artística. Esta prescripción estilística con propósito evangelizador intentó consolidar el repertorio formal que se venía configurando desde el siglo XVII, quizá también como estrategia para contener la creciente agitación social en la región.

Como resultado, en todo el ámbito cultural surandino, el encargo y creación de obras de arte y arquitectura religiosas adquirió gran relevancia. Los materiales fueron múltiples. La inspiración y la iconografía, reveladoras de vertientes diversas, reunidas en la confluencia de los motivos autóctonos y la imaginería europea. Durante dos siglos, albañiles, carpinteros, canteros, artistas, pintores y doradores: indígenas de distintas etnias replicaron y adornaron los templos según estos patrones estéticos característicos, surgidos como una creación única y original a lo largo de la Ruta de la Plata.

Finalmente, la fecunda irradiación de este estilo también alcanzó a los pueblos y templos de doctrinas y caminos subsidiarios, definiendo un ámbito de singular riqueza artística y cultural. Las numerosas investigaciones realizadas sobre los templos surandinos demuestran la riqueza del aporte realizado por los artífices locales, sobre cuya obra aún queda mucho por develar.

Transcurridos más de dos siglos desde su edificación, las iglesias de la Ruta de la Plata y su ornamentación dan cuenta de la red

20 ACLP, Tomo 101, f. 54. 
de significados, creencias, saberes y costumbres que nacieron del encuentro de dos civilizaciones, en el crisol donde se fundió la cosmovisión de los pueblos surandinos con la cultura que los conquistadores españoles trajeron consigo a América.

Muchos de estos templos continúan siendo, para las comunidades que los han usado como centros ceremoniales desde hace más de dos siglos, un referente de su religiosidad, de su identidad y de su historia. Ellos son un espejo vivo que continúa reflejando las dos vertientes que dieron vida a un nuevo mundo.

\section{FUENTES DOCUMENTALES}

Archivo de Indias

Álvarez Jiménez. Visita al partido de Arica, 1793. Manuscrito. Archivo de Indias, $\mathrm{N}^{\circ} 48$.

El Obispo da cuenta a Su Majestad del estado del Obispado de Arequipa, 1636. Lima 309.

Descripción de América Meridional, 1788.

Archivo Arzobispado de Arequipa

Legajo Arica-Codpa 1650-1893.

Legajo Arica-Belén 1694-1856.

Legajo Arica 1616-1877.

Archivo Capitular de La Paz. Canónigo Felipe López Menéndez.

Tomo 11 (1684), Cuaderno de los gastos por menor que se hacen en esta iglesia de Italaque y han de pasar al libro de fábricas a favor de don Miguel Galaz de los Ríos.

Archivo Arzobispado Sucre. Monseñor Santos Taborga.

Autos fulminados por el señor visitador Don Francisco de Zamora Montes Negro, contra el doctor Min, De Lenis y Gamboa, cura propio del Beneficio de Corquemarca en 6 de julio año 1680.

Oposiciones, ff., s/n. 
Archivo parroquia San Miguel de Pomata.

Libro de fábrica 1621-1700, Pomata, 1663-1664.

Expensas e inventarios antiguos San Miguel de Pomata 1708-1764, s/n.

Archivo Obispado de Arica.

Libro de fábrica e inventario de la Doctrina de Codpa 1870-1899, 1870-1907. Libro N. ${ }^{\circ}$ 13, de fábrica e inventario de la viceparroquia de Putre 1793-1900. Libro parroquial de entierros. Parroquia de Codpa 1813.

Ministerio de Relaciones Exteriores del Perú. Departamento de archivo de límites. N. ${ }^{\circ}$ Ari-1. Legajo 416. Siglo XVIII. Inventario que se hace de las iglesias. N. ${ }^{\circ}$ de folios: 65. Año: 1778-1837.

\section{REFERENCIAS}

BAILEy, Gauvin

2010 The Andean Hybrid Baroque: Convergent Cultures in the Churches of Colonial Peru. Indiana: University of Notre Dame.

BARRIGA, Irma

2010 Patrocinio, Monarquia y poder: el glorioso patriarca señor san Joseph en el Perú virreinal. Lima: Pontificia Universidad Católica del Perú - Instituto Riva-Agüero.

BARRIGA, Víctor

1952 Memorias para la Historia de Arequipa. Arequipa: Imprenta Portugal.

Bouysse-Cassagne, Thérèse

1987 Identidad aymara: Aproximación histórica (s. XV, s. XVI). La Paz: Hisbol-Ifea.

Campos y Fernández de Sevilla, F. Javier (ed.)

2014 Catálogo de Cofradías del Archivo del Arzobispado de Lima. Madrid: Colección del Instituto Escurialense de Investigaciones históricas y artísticas, n. 42. 
CARr, Dennis et ál.

2015 Made in the Americas: The New World Discovers Asia. Boston: Museum of Fine Arts.

Casassas Cantó, José María

1974 «Algunas noticias sobre los partidos de Arica y Tarapacá hacia fines del siglo XviII y principios del XIX». Norte Grande, vol. 1, n. 2. Santiago: Instituto de Geografía, Universidad Católica de Chile.

Castro Flores, Nelson, Juan Chacama Rodríguez y Ricardo Mir Román 2009 «Excitar y subyugar. Pastoral de la imagen y poblaciones indígenas en Arica colonial». Diálogo Andino, n. 34. Arica: Universidad de Tarapacá, pp. 25-43.

Chacama Rodríguez, Juan

2009 «Imágenes y palabras, dos textos para un discurso: La prédica pastoral en los Andes coloniales. Doctrina de Codpa (Altos de Arica), siglo xviII». Diálogo Andino, n. 33. Arica: Universidad de Tarapacá, pp. 7-27.

Choque, Roberto

2003 Jesús de Machaca, La marka rebelde. Cinco siglos de Historia. La Paz: Plural Ediciones.

CoHen Suarez, Ananda

2016 Heaven, Hell and Everything in Between: Murals of the Colonial Andes. Austin: University of Texas.

Cortés Castellanos, Justino

1987 El catecismo en pictogramas de Fr. Pedro de Gante. Madrid: Fundación Universitaria Española.

CorTi, Paola, Fernando Guzmán y Magdalena Pereira

2010 «El Juicio Final de Parinacota en el contexto del programa iconográfico de los murales del templo». En: Entre Cielos e Infiernos: Memoria del $V$ Encuentro Internacional sobre Barroco. La Paz: GRISO y Unión Latina. 
2010 «El Juicio Final de Curahuara de Carangas y Parinacota». En: Entre Cielos e Infiernos: Memoria del $V$ Encuentro Internacional sobre Barroco. La Paz: GRISO y Unión Latina.

2011 «El indio trifronte de Parinacota, un enigma iconográfico». Colonial Latin-American Review, vol. 20, n. 3, pp. 393-395.

2013 La pintura mural de Parinacota en el último bofedal de la Ruta de la Plata. Santiago: Ediciones Ograma.

2016 «Imágenes que evangelizan en la Ruta de la Plata: El programa iconográfico del baptisterio de la iglesia de Curahuara de Carangas». Goya. Revista de Arte, 356, pp. 226-237.

Cummins, Thomas

2002 Toasts with the Incas. Michigan: University of Michigan Press.

Danigno, Vicente

1909 El corregimiento de Arica: 1535-1784. Arica: Imprenta La Época.

Durand Flórez, Luis

1993 El proceso de independencia en el sur andino. Cuzco y La Paz 1805. Lima: Universidad de Lima.

Durston, Alan y Jorge Hidalgo

2004 «La presencia andina en los valles de Arica, siglos XVI-XVIII: Casos de regeneración colonial de estructuras archipielágicas» y «Reconstitución étnica colonial en la sierra de Arica: El cacicazgo de Codpa, 1650-1780». Historia andina de Chile. Santiago: Editorial Universitaria.

ESCOBARI, Laura

2012 Caciques, yanaconas y extravagantes: Sociedad y educación colonial en Charcas, siglos XИ1-ХVIII. La Paz: Plural Editores.

2014 Producción y comercio en la historia de Bolivia colonial, siglos ХИ-ХИІІІ. La Paz: Plural Editores.

Flores OchOA, Jorge, Elisabeth Kuon Arce y Roberto Argumedo Samanez 1993 Pintura mural en el sur andino. Lima: Banco de Crédito del Perú.

1998 Queros: Arte inka en vasos ceremoniales. Lima: Banco de Crédito del Perú. 
García Quintanilla, Julio

1964 Historia de la Iglesia en La Plata. Sucre: Talleres Gráficos Don Bosco.

GisBert, Teresa

1982 «El barroco andino y el estilo mestizo». En: Simposio Internazionale sul Barocco Latino Americano. Vol. 2. Roma: Instituto Ítalo-Latinoamericano.

1986 La tradición bíblica en el arte virreynal. La Paz: Editorial Los Amigos del Libro.

1990 «Arquitectura, cristianización e idolatría». En: La evangelización del Perú: siglos ХИ у ХVII. Actas del Primer Congreso Peruano de Historia Eclesiástica. Arequipa: Arzobispado de Arequipa.

1992 «Los curacas del Collao y la conformación de la cultura mestiza andina». Senri Ethnological Studies, n. 33. Japan: National Museum of Ethnology.

2001 Elparaíso de los pájaros parlantes: La imagen del otro en la cultura andina. La Paz: Editorial Gisbert.

2004 Iconografia y mitos indígenas en el arte. La Paz: Editorial Gisbert.

Gisbert, Teresa, Silvia Arze y Martha Cajías

2006 Arte textily mundo andino. La Paz: Plural Editores.

Gisbert, Teresa y Carlos Rosso

2008 La iglesia de Curabuara de Carangas. La Paz: Plural Editores.

Gisbert, Teresa y José de Mesa

1997 Arquitectura andina. La Paz: Embajada de España en Bolivia.

2012 Historia del arte en Bolivia. Periodo virreinal. La Paz: Editorial Gisbert.

GLAve, Miguel

1989 Trajinantes, caminos indigenas en la sociedad colonial. Lima: Instituto de Apoyo Agrario.

GuARDA, Gabriel

2007 «Arte y evangelización en Chile. Siglos XVI-XVIII». Boletin de la Academia Chilena de la Historia, n. 116, pp. 65-82. 
Guido, Ángel

1944 Redescubrimiento de América en el arte. Buenos Aires: El Ateneo.

GuTIÉrReZ, Ramón et ál.

1986 Arquitectura del altiplano peruano. Buenos Aires: Libros de Hispanoamérica.

GuZMÁn, Fernando et ál.

2016 «Programa iconográfico y material en las pinturas murales de la iglesia de San Andrés de Pachama, Chile». Colonial Latin American Review, vol. 25, n. 2, pp. 245-264.

Guzmán, Fernando, Paola Corti y Magdalena Pereira

2014 «Imagen y palabra en la evangelización y catequesis de la Ruta de la Plata. Potosí-Arica». Hispania Sacra, n. 66, Extra II, pp. 119-68.

Guzmán, Fernando y Magdalena Pereira

2012 «La pintura mural y la crisis del poder en dos iglesias de la Ruta de la Plata», Barroco y Poder. La Paz: GRISO y Unión Latina.

Hidalgo, Jorge (ed.)

2004 Historia andina en Chile. Santiago: Editorial Universitaria.

Jemio, Juan Carlos (coord.)

1998 Pintura mural en el área centro sur andina. La Paz: Hisbol.

León Pinelo, Antonio de

1943 El Paraíso en el nuevo mundo. Tomo I. Editado por Raúl Porras Ba[1656] rrenechea. Lima: Publicado bajo los auspicios del Comité del IV Centenario del Descubrimiento del Amazonas.

LiZÁrRaga, Reginaldo de

1908 Descripción y población de las Indias. Lima: Instituto Histórico del Perú. Imprenta Americana.

López Beltrán, Clara

2015 La Ruta de la Plata: de Potosí al Pacífico. La Paz: Plural Ediciones. 
Mannheim, Bruce

2012 Leer a Juan Pérez. Bocanegra, su Ritual Formulario y Hanaq pachap kusikuynin. Cusco: Universidad San Antonio Abad.

MARTínez, José Luis

2010 «"Mandó pintar dos aves..." relatos orales y representaciones visuales andinas». Chungará, vol. 42, n. 1, pp. 157-167.

Mebold, Luis

1985 «La pintura religioso-popular del altiplano chileno». Aisthesis, n. 15, pp. 62-80. Santiago: Instituto de Estética, Universidad Católica de Chile.

Medinacelli, Ximena

2010 Sariri, los llameros y la construcción de la sociedad colonial. La Paz: Instituto Francés de Estudios Andinos.

Medinacelli, Ximena y Cleverth Cárdenas

2013 Iglesias y fiestas en el altiplano de La Pazy Oruro. Aproximaciones multidisciplinarias. La Paz: Musef Editores.

Mesa, José de y Teresa Gisbert

1971 «Lo indígena en el arte hispanoamericano». Boletín del centro de investigaciones históricas y estéticas. Caracas: Universidad Central de Venezuela.

Millones, Luis

1987 Historia y poder en los Andes Centrales. Madrid: Alianza Editorial.

Millones, Luis y Hiroyasu Tomoeda

2004 «Las sirenas de Sarhua». Letras, año Lxxv, n. 107-108, pp. 15-31.

Moreno, Rodrigo y Magdalena Pereira

2011 Arica y Parinacota: La Iglesia en la Ruta de la Plata. Viña del Mar: Ediciones Altazor. 
MuÑóz, Iván

1983 «Hallazgo de un Alouatta Seniculus en el valle de Azapa. Estudio preliminar de la iconografía de simios en Arica». Chungará, n. 10, pp. 39-46.

MurRA, John

2009 El mundo andino, población, medio ambiente y economía. Lima: Instituto de Estudios Peruanos.

Noel, Martín

1948 Rutas históricas en la arquitectura virreinal alto peruana. Cuaderno V. Buenos Aires: Academia Nacional de Bellas Artes.

OCAÑa, Diego de

2010 Viaje por el Nuevo Mundo: de Guadalupe a Potosí, 1599-1605. Edición de Blanca López de Mariscal y Abraham Madroñal. Centro de Estudios Indianos de la Universidad de Navarra. Biblioteca Indiana, 22. Madrid: Iberoamericana.

OKADA, Hiroshige

2006 «Inverted Exoticism, monkeys, parrots, and mermaids in Andean colonial art». En: Suzanne Stratton-Pruit (ed.). The Virgin, Saints and Angels: South American Paintings, 1600-1825, from the Thoma Collection. Stanford: Stanford University Press, pp. 67-79.

2014 «Mural painting in the viceroyalty of Peru». En: Elena Alcalá y Jonathan Brown (eds.). Painting in Latin America 1550-1820. Yale: Yale University, pp. 403-435.

O’Phelan Godoy, Scarlett

2012 Un siglo de rebeliones anticoloniales, Perú y Bolivia, 1700-1783. Lima: Instituto de Estudios Peruanos.

Pereira, Magdalena

2011 «La conservación del arte religioso andino en Arica y Parinacota en tiempos de posguerra (1884-1907)». En: Marcial Sánchez (ed.). Historia de la Iglesia en Chile. Tomo III. Santiago: Editorial Universitaria, pp. 367-393. 
2014 «Arte y devoción en la Ruta de la Plata: Platería en las iglesias andinas de Arica y Parinacota, Chile (S. XVII-XIX)». En: Jesús Paniagua Pérez et ál. (coord.). Aurea quersoneso, estudios sobre la plata iberoamericana. Siglos XVI-XIX. Porto: Centro de Investigação em Ciência e Tecnologia das Artes da Universidade Católica Portuguesa, pp. 281-300.

Pereira, Magdalena (ed.)

2013 Socoroma, restauración de la Iglesia de San Francisco de Asís. Santiago: Subsecretaría de Desarrollo Regional.

Phipps, Elena

2013 «The Iberian Globe: Textile Traditions and Trade in Latin America». En: Amelia Peck (ed.). Interwoven Globe: The Worldwide Textile Trade, 1500-1800. Nueva York: The Metropolitan Museum of Art.

Platt, Tristán et ál.

2011 Qaraqara-Charca, mallku, Inka y Rey en la provincia de Charcas (siglos $X V$-XVII). Arequipa: IFEA.

Riviere, Gilles

1979 «Intercambio y reciprocidad en Caranga». Antropología, n. 1 (1), pp. 85-113. La Paz: Instituto Nacional de Antropología.

SALAZAR-SOLER, Carmen

2013 «Los capitanes de mita y el conteo de indios en las minas del Cerro Rico de Potosís. En: Marcos Curatola y otro (eds.). El quipu colonial. Estudios y materiales. Lima: Pontificia Universidad Católica del Perú.

SCHAUER, Phillip

2010 Iglesias rurales LaPazy Oruro. La Paz: Editorial Gisbert.

SERRERA, Ramón

1999 Tráfico terrestre y red vial en las indias españolas. Madrid: Lunwerg Editores. 
Sinodales

1854 Constituciones Sinodales del arzobispado de la Plata del Consejo de su Majestad, concluidas en la dicha ciudad de la Plata en once de Julio de 1773 años, y aprobadas por los señores de la Real Audiencia de ella en 18 de noviembre del mismo año y vigentes en las diócesis de la República. Cochabamba: Imprenta de los Amigos.

Siracusano, Gabriela

2010 La paleta del espanto, color y cultura en los cielos e infiernos de la pintura colonial andina. Argentina: Universidad Nacional San Martín.

STANFIELD-Mazzi, Maya

2013 Object and Apparition. Tucson: The University of Arizona Press.

TANDETER, Enrique

1992 Coacción y mercado: La minería de la plata en el Potosí colonial, $1692-$ 1826. Madrid: Siglo XXI.

Toledo, Francisco de

1986 Disposiciones gubernativas para el virreinato del Perú, 1569-1574. Editado por Justina Sarabia. Sevilla: Escuela de Estudios Hispanoamericanos de Sevilla.

Villanueva Urteaga, Horacio

1989 «Los Mollinedo y el arte del Cuzco colonial». Boletin del Instituto Riva-Agüero, n. 16, pp. 209-219.

WALKER, Charles F.

1999 De Túpac Amaru a Gamarra: Cusco y la formación del Perú republicano: 1780-1840. Cusco: Centro de Estudios Regionales Andinos Bartolomé de Las Casas. 
